\title{
Natural bioactive compounds and antimicrobial potential of Pavetta indica L.
}

\begin{abstract}
Terrestrial plants have opened up a new perspective for pharmaceutical research and development of novel antimicrobial agents for the treatment of microbial diseases. Therefore, it is necessary to start an urgent need to screen the plants for novel bioactive compounds. In this context, present study was carried out to screen phytochemical constituents from leaves of Pavetta indica L., and its antimicrobial potential. $P$. indica leaves possess Chlorophyll $a\left(1.21 \pm 0.05 \mathrm{mg} \mathrm{g}^{-1}\right)$, Chlorophyll $b\left(1.61 \pm 0.09 \mathrm{mg} \mathrm{g}^{-1}\right)$, total chlorophyll $(2.82 \pm 0.13 \mathrm{mg}$ $\left.\mathrm{g}^{-1}\right)$, carotenoids $\left(0.57 \pm 0.06 \mathrm{mg} \mathrm{g}^{-1}\right)$, total soluble sugars $\left(30.08 \pm 0.79 \mathrm{mg} \mathrm{g}^{-1}\right)$, total soluble starch $(13.54 \pm 0.72)$, total soluble proteins $\left(47.81 \pm 2.82 \mathrm{mg} \mathrm{g}^{-1}\right)$, total free amino acids $\left(5.77 \pm 0.69 \mathrm{mg} \mathrm{g}^{-1}\right)$, total phenol $\left(7.67 \pm 0.72 \mathrm{mg} \mathrm{g}^{-1}\right)$, hydroxyl phenols $(5.74 \pm 0.29 \mathrm{mg}$ $\left.\mathrm{g}^{-1}\right)$ and lipids $\left(53.53 \pm 2.50 \mathrm{mg} \mathrm{g}^{-1}\right)$ while alkaloids, tannins, steroids, phenolic compounds, saponins, triterpenoids and cardiac glycosides were also present in the leaves of $P$. indica. Absolute ethanolic extract of $P$. indica showed significant antimicrobial activity against all the tested pathogens, followed by aqueous extract. In concluded that, $P$. indica leaves crude extracts have wide range of bioactive compounds and which might be led to potential antimicrobial activity. They may lend to developing novel therapeutic agent to different infectious diseases.
\end{abstract}

Keywords: phytochemical constituents, antimicrobial, pavetta indica, ethanolic extract, therapeutic agent
Volume 10 Issue 4 - 202I

\author{
Gobalakrishnan R,' Bhuvaneswari R² \\ 'District Institute of Education and Training, Pudukkottai - \\ 622004, Tamilnadu, India \\ ${ }^{2}$ Government Girls Higher Secondary School, Aranthangi \\ 614616, Tamilnadu, India
}

Correspondence: Gobalakrishnan R, District Institute of Education and Training, Pudukkottai - 622004, Tamilnadu, India, Tel+9|-8I 24800850, Email gobalaldy@gmail.com

Received: August 06, 202I | Published: August 27, 2021

\section{Introduction}

In the world's population, 60 percentage of people are followed the traditional medicines. These are not only used for primary health care not just in rural areas in developing countries. The traditional medicines are derived from medicinal plants, minerals, and organic matter and the herbal drugs are prepared from medicinal plants only. ${ }^{1}$ India, a country of eternity rich in tradition, history and ideal for its cultural heritage and it is endowed with a rich wealth of medicinal plants. These plants have made a good contribution to the development of ancient Indian materia medica. ${ }^{2}$ Most of these continue to be gathered from wild plants to meet the demand of the medical profession. ${ }^{3}$ Thus, despite the rich heritage of knowledge on the use of plant drugs, little attention has been paid to grow them as field crops in the country till the latter part of the nineteenth century.

People were suffering daily, without getting perfect recovery from the various diseases although they underwent a costly allopathic system of treatment with more side effects. Consequently, it is very urgency to go back to "Natural medicine". The herbal medicines are less toxic, more potent, and cheap and have little side effects and these are easily available even in remote places, culturally accepted and cure not only the diseases but also set right many disorders. ${ }^{4}$ Most of these plants are known to us and available as naturally. So, past seven or eight decades, the knowledge of herbal based medical treatment has been improved rapidly in India.

Higher plants produce innumerable of diverse chemical compounds with different biological activities. ${ }^{5}$ It is believed that these compounds have an important ecological role and they can work as pollinator attractants. ${ }^{6}$ In addition, plant extracts are known to be effective defenses agent against various pathogens. ${ }^{7}$ Therefore, it generated a commercial demand for pharmacopoeial drugs and products in the country, thus efforts were made to introduce many of these medicinal plants into screening studies. In this context, present study was carried out to a screening of phytochemical constituents from leaves of Pavetta indica L., and its antimicrobial potential.

The plant species of $P$. indica $\mathrm{L}$., belonging to the family Rubiaceae and this habitat is dry regions, in the wastelands, common on scrub jungles, an erect, nearly smooth or somewhat hairy shrub habit, Stiff and branchlets pale brown in stem, opposite, elliptic-oblong to elliptic-lanceolate in leaves, inflorescence a terminal or axillary and trichotomously branched corymbose cymes, flowers are bisexual, calyx lobes 4 , corolla 4 lobed rarely 5 , stamens 4 rarely 5 , ovary 2 celled, berry type fruit, seeds (1-2, small, pyrenes) and phenology of the flowering and fruiting period is November to February (Figure 1).

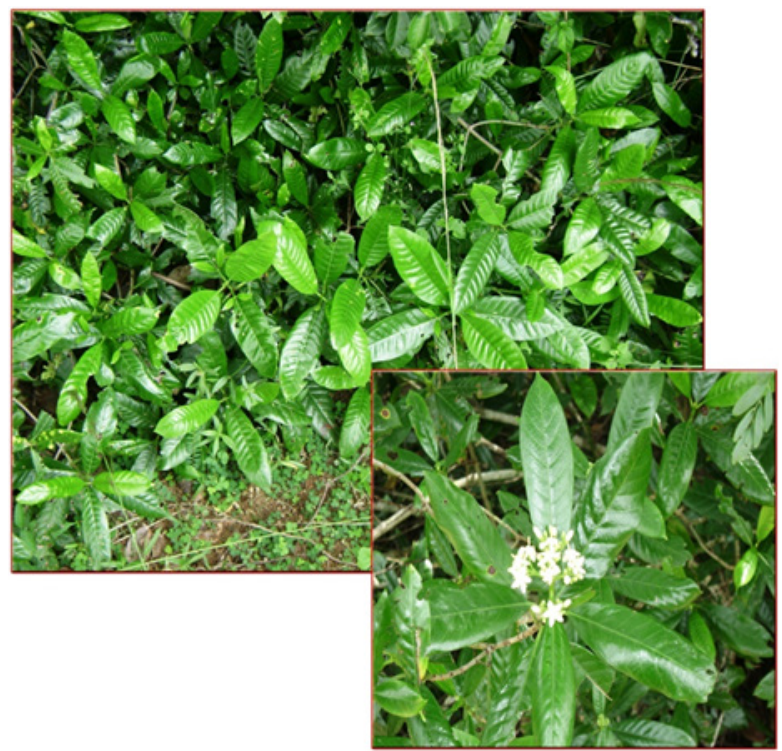

Figure I Photographs displaying distinct as well as closer views of $P$. indica $\mathrm{L}$. 


\section{Materials and methods}

\section{Collection of plant materials}

Fine plant species was collected from the various areas of Pudukkottai District, Tamilnadu, India in the month of November and December. Plant species was identified using Rapinat Herbarium, St. Joseph's College, Trichy and same plant specimens were deposited in the Research and PG department of Botany, H.H. The Rajah's College, Pudukkottai. The collected plants were thoroughly washed with water and the parts of plant were separated and kept in dark room at room temperature covered with filter papers to get rid off moisture for further analysis.

\section{Biochemical screening}

Biochemical tests in the leaf of $P$. indica were done using standard methods, which was adapted by Gobalakrishnan et al. ${ }^{8}$

\section{Preparation of extract}

Dried out plant materials were powdered with Waring blender, at room temperature and 1 gram of the samples were soaked in $10 \mathrm{ml}$ of different solvents (Aqueous, 25\% ethanol, 50\% ethanol, 75\% ethanol and $100 \%$ ethanol) at overnight. Later, the samples were filtered under vacuum using Whatmann No. 1filter paper and stored in screw-capped bottles at $5^{0} \mathrm{C}$ for future studies.

\section{Preparation of inoculum}

Seven clinical pathogens were obtained from the Microbial Clinical Laboratory, KMC Hospital, Trichy. Out of the seven, four strains were bacteria (Escherichia coli, Salmonella typhi, Bacillus subtilis and Streptococcus pyogenes) and three strains were fungi (Aspergillus niger, Albugo candida and Trichophyton rubrum). The techniques of the preparation and storage of inoculum for the both bacteria and fungi were adopted by Gobalakrishnan et al. ${ }^{8}$

\section{In-vitro antimicrobial study}

Spectrum of antimicrobial activity was studied by using the techniques described by Bauer et al. ${ }^{9}$ As a positive control, the streptomycin sensitivity disc $(10 \mu \mathrm{g} /$ disc; Hi-Media) was used and respective solvents were used as a negative control. At the end of incubation period, zone of inhibition was measured around the disc with transparent ruler in millimeter. These studies were performed in triplicate.

\section{Result and discussion}

Since ancient periods, plants have been an actual source of medicines. However, human tends to ignore the important of herbal medicine and traditional medicinal plants have been tested to identify the source of the therapeutic effects. ${ }^{10}$ In addition, the primary phytochemical investigation of the plants is very important to identify novel source of therapeutically and pharmaceutically vital compounds and it is necessary to start an urgent need to screen the plants for novel bioactive compounds. ${ }^{11}$ Therefore, the present study was screened of phytochemical constituents from leaves of $P$. indica. The results of the biochemical screening, $P$. indica leaves were presented: Chlorophyll $a\left(1.21 \pm 0.05 \mathrm{mg} \mathrm{g}^{-1}\right)$, Chlorophyll $b\left(1.61 \pm 0.09 \mathrm{mg} \mathrm{g}^{-1}\right)$, total chlorophyll $\left(2.82 \pm 0.13 \mathrm{mg} \mathrm{g}^{-1}\right)$, carotenoids $\left(0.57 \pm 0.06 \mathrm{mg} \mathrm{g}^{-1}\right)$, total soluble sugars $\left(30.08 \pm 0.79 \mathrm{mg} \mathrm{g}^{-1}\right)$, total soluble starch $(13.54$ $\pm 0.72)$, total soluble proteins $\left(47.81 \pm 2.82 \mathrm{mg} \mathrm{g}^{-1}\right)$, total free amino acids $\left(5.77 \pm 0.69 \mathrm{mg} \mathrm{g}^{-1}\right)$, total phenol $\left(7.67 \pm 0.72 \mathrm{mg} \mathrm{g}^{-1}\right)$, hydroxyl phenols $\left(5.74 \pm 0.29 \mathrm{mg} \mathrm{g}^{-1}\right)$ and lipids $\left(53.53 \pm 2.50 \mathrm{mg} \mathrm{g}^{-1}\right)$. Further, alkaloids, tannins, steroids, phenolic compounds, saponins, triterpenoids and cardiac glycosides were also present in the leaves of P. indica (Table 1). These phytochemicals are plant-derived chemical compounds which are non-essential nutrients, some of which show potential health-promoting properties. ${ }^{12}$

Antimicrobial activity of $P$. indica leaves crude extract was analyzed against four bacteria (E. coli, B. subtilis, S. typhi, S. pyogenes) and three fungi (A. niger, A. candida and T. rubrum) and their results are presented in Table 2. Absolute ethanolic extract of $P$. indica showed significant antimicrobial activity against all the tested pathogens, followed by aqueous extract. The absolute ethanolic extract showed the maximum $(21 \pm 0.2 \mathrm{~mm})$ inhibition zone while aqueous extracts showed minimum $(6 \pm 0.4 \mathrm{~mm})$ inhibition zone against $E$. coli. Successive isolation of plant bioactive compounds from plant material is largely dependent on the type of solvent used in the extraction procedure. The traditional therapists use primarily water as the solvent. ${ }^{10,13}$ In the present study $P$. indica plant extracts prepared with ethanol as solvents provided more consistent antimicrobial activity than the aqueous crude extracts. This might have lack of solubility of the active constituents in aqueous solvents. ${ }^{10}$ It is worth mentioning here that the ethanol formulations are relatively safe for human consumption. ${ }^{8}$

Plants generally produce many secondary metabolites which constitute an important source of microbicides, pesticides and many pharmaceutical drugs. ${ }^{10}$ In literatures registered some bioactive compounds such as alkaloids, tannins, steroids, phenolic compounds, saponins, triterpenoids and cardiac glycosides were played important inhibitory role against pathogens. ${ }^{14,15}$ Similarly, present studied $P$. indica leaves extracts revealed different bioactive compounds and which compounds might be responding to inhibit the tested microorganisms. Those bioactive compounds directly or indirectly interfere the physiological process of the microorganism include the major targets of pore formation in the cell wall, leakage of cytoplasmic constituents, ${ }^{16}$ inhibit cell wall biosynthesis, protein synthesis and nucleic acid production. Likewise, Gupta et al. ${ }^{17}$ studied $P$. indica leaf antimicrobial activity against B. subtilis, E. coli and $S$. cerevisiae and revealed presence of flavonoids, saponins and carbohydrates. Nandagopalan et al..$^{18}$ also reported that $P$. indica had an anti-inflammatory and antimicrobial property. Ramamurthy et al. ${ }^{19}$ reported that leaf of $P$. indica extract was acting potential diuretic agent and Duraipandian et al. ${ }^{20}$ mentioned that $P$. indica root powder was used for relief indigestion. Natarajan et al. ${ }^{21}$ reported that the methonol extract of $P$. indica (at the doses of $400 \mathrm{mg} / \mathrm{kg}$ ) significantly reduced blood sugar level.

Table I Bioscreening of phytochemical constituents from Pavette indica L., leaf extracts

\begin{tabular}{lllllllll}
\hline Plant & Alkaloids & Tannin & Steroid $l$ & Phenolic & Fatty & Flavonoid & Anthracenel & Volatile \\
\hline parts & & & Triterpenoids & compounds & acid & & Glycosides & oils \\
Leaf & ++ & ++ & + & +++ & - & + & + & -
\end{tabular}

+ (Presence of constituents, +++ (High); ++ (Moderate)), - (Absence of constituents) 
Table 2 Antimicrobial activity of P. indica leaves extracts

\begin{tabular}{llllllll}
\hline S.No & Tested Organisms & \multicolumn{6}{l}{ Inhibition zone of diameter $(\mathbf{m m})}$. \\
\hline & Bacteria & A & B & C & E & F & Streptomycin (+) disc \\
\hline I & E. coli & $6 \pm 0.4$ & $8 \pm 0.2$ & $9 \pm 0.3$ & $9 \pm 0.6$ & $21 \pm 0.2$ & 24.5 \\
2 & S. typhi & $7.1 \pm 0.4$ & - & - & - & $19.7 \pm 0$ & 23.2 \\
3 & B. subtitles & $6.5 \pm 0.3$ & - & - & $7.2 \pm 0.2$ & $12 \pm 0.3$ & 18 \\
4 & S. pyogenes & - & - & - & - & $8 \pm 0.6$ & 14.7 \\
& Fungi & & - & - & & & \\
5 & A. niger & - & - & - & - & $7.3 \pm 0.2$ & 17.5 \\
6 & A. candida & - & - & - & - & $6.3 \pm 0.6$ & 11.6 \\
7 & T. rubrum & - & - & - & - & $6.1 \pm 0.3$ & 11.3
\end{tabular}

Aqueous (A), 25\% ethanol (B), 50\% ethanol (C), 75\% ethanol (E), $100 \%$ ethanol (F), No activity (-).

Values are mean \pm standard deviation of three determinations.

\section{Conclusion}

In conclusion, plants are one of the most commonly used natural antimicrobial agents and have been used traditionally from the ancient period by many cultures. Even though a significant number of studies have been used to obtain purified plant chemical, very few screening reports have been initiated on crude plant material which also widely observed and accepted and also the wild plant has opened up a new perspective in pharmaceutical research and they can be used for the development of potential, novel antimicrobial agents for the treatment of microbial diseases. In this context present studied $P$. indica leaves crude extracts have wide range of bioactive compounds. These compounds had potential antimicrobial activity and they may lend to developing novel therapeutic agent to different infectious diseases.

\section{Acknowledgments}

Authors are thankful to the Principal, H.H. The Rajah's college, for facilities to carried out the work. They also thank Dr. S. Thangarasu, Professor for their guidance. The author (R.G.) thanks the Director and Joint Directors, SCERT, Chennai and Dr. P. Natarajan, Principal, District Institute of Education and Training, Pudukkottai, for providing with necessary support. The contents and views reported in this manuscript are of individual authors and not reflect the views and/ or positions of the institutions they belong.

\section{Conflicts of interest statement}

The authors declare no conflict of interest regarding publication of this manuscript.

\section{References}

1. Joseph B, Jini D. Insight into the hypoglycaemic effect of traditional Indian herbs used in the treatment of diabetes. Research Journal of Medicinal Plant. 2011;5:352-376.

2. Chauhan AK, Varma A. Microbes: Health and Environment, I. K. International Pvt Ltd. New Delhi, India. 2006. p. 436.

3. Gobalakishnan R, Kulandaivelu M, Bhuvaneswari R, et al. Screening of wild plant species for antibacterial activity and phytochemical analysis of Tragia involucrata L. Journal of Pharmaceutical Analysis. 2013;3(6):460-465.
4. Pandey M, Subha Rastogi M, Rawat AKS. Indian traditional ayurvedic system of medicine and nutritional supplementation. Evidence-based Complementary and Alternative Medicine. 201;2:article ID 376327.

5. Hamburger M, Hostettmann K. Bioactivity in plants: the link between phytochemistry and medicine. Phytochemistry. 1991;30:3804-3814.

6. Saito N, Harborne JB. Correlations between anthocyanin type, pollinator and flower colour in the Labiatae. Phytochemistry. 1992;31:3009-3015

7. Lamothe RG, Mitchell G, Gattuso M, et al. Plant Antimicrobial agents and their effects on plant and human pathogens. International Journal of Molecular Sciences. 2009;10:3400-3419.

8. Gobalakrishnan R, Manikandan P, Bhuvaneswari R. Antimicrobial potential and bioactive constituents from aerial parts of Vitis setosa Wall. Journal of Medicinal Plants Research. 2014;8(11):454-460.

9. Bauer AW, Kirby E, Sherris EM, et al. Antibiotic by standardized single disk method. American Journal of Clinical Pathology. 1966;45:493-496.

10. Parekh J, Chanda S. In-vitro antimicrobial activity and phytochemical analysis of Indian medicinal plants. African Journal of Biological Research. 2017;10:175-181.

11. Savithramma N, Linga Rao M, Bhumi G. Phytochemical screening of Thespesia populnea (L.) Soland and Tridax procumbens L. Journal of Chemical and Pharmaceutical Research. 2011;3(5):28-34.

12. Hussain AI, Anwar F, Iqbal T, et al. Antioxidant attributes of four Lamiaceae essential oils. Pakistan Journal of Botany. 2011;43(2):1315-1321.

13. Aliero AA, Afolayan AJ. Antimicrobial activity of Solanum tomentosum. African Journal of Biotechnology. 2006;5(4):369-372.

14. Alagesaboopathi C, Sivakumar R. Antimicrobial properties of various extracts of Andrographis neesiana Wight. an endemic medicinal species from India. International Journal of Pharm Tech Research. 2011;3(1), $27-31$.

15. Bhuvaneswari R, Gobalakrishnan R. Antimicrobial potential and structural elucidation of bioactive compounds from flower extract of Cassia javanica L. Indian Journal of Natural Product Resources. 2014;5(1):34-39.

16. Gnanamani A, Priya KS, Radhakrishnan N, et al. Antibacterial activity of two plant extracts on eight burn pathogens. Journal of Ethanopharmacology. 2003;86(1):59-61.

17. Gupta VK, Kaur C, Simlai A, et al. Antimicrobial activity in Pavetta indica leaves. Journal of Applied Pharmaceutical Science. 2013;3(04):78-82. 
18. Nandagopalan V, Anand SP, Lakshmi Prabha A, et al. An ethnobotanical study in the Pudukkottai District, South India. Asian Journal of Experimental Biological Sciences. 2011;2:412-421.

19. Ramamurthy J, Venkataraman S, Meera R, et al. Phytochemical investigation of Pavetta indica. International Journal of Chemical Sciences. 2011;9(1):397-402.
20. Duraipandiyan V, Ayyanar M, Ignacimuthu S. Antimicrobial activity of some ethnomedicinal plants used by Paliyar tribe from Tamil Nadu, India. BMC Complementary and Alternative Medicine. 2006;6(35):1-7.

21. Natarajan P, Thangathirupathi A, Ramarajan S. Preliminary study of antidiabetic activity of methanolic extract of Pavetta indica Linn in diabetic rats. Asian Journal of Pharmaceutical and Clinical Research. 2013;6(1):131-133. 